\title{
Haematologist-reviewed peripheral blood smear in paediatric practice
}

Anselm Chi-wai Lee, MBBS, FAMS

\begin{abstract}
Manual examination of the peripheral blood smear (PBS) is currently performed on a fraction of samples sent for automated complete cell count. 39 children (age range $0-16.2$ years) referred to a private paediatric practice during a 16-month period were retrospectively reviewed. Clinical scenarios, haematological features, laboratory-initiated PBS review, haematologist's PBS review and final diagnosis were described. Clinical indications included isolated thrombocytopenia $(n=10)$, unexplained bruises $(n=5)$, acute febrile illnesses $(n=11)$, anaemia $(n=8)$ and others $(n=5)$. The laboratory reviewed the PBS in 30 cases according to preset criteria and made no conclusive remarks. All slides were reviewed by a haematologist and a diagnosis was made in 27 (69\%) cases, including 7 (78\%) of the nine slides the laboratory did not review. The practice of laboratory-initiated PBS review requires re-evaluation. Haematologist-reviewed PBS is an important diagnostic tool for children with anaemia, bleeding disorders and acute febrile illnesses.
\end{abstract}

Keywords: blood cell count, child, diagnostic techniques and procedures, paediatric haematology, peripheral blood smear

\section{INTRODUCTION}

Examination of the peripheral blood smear (PBS) used to be an integral part of a complete blood count (CBC). However, given that contemporary automated blood cell analysers can now provide fast and accurate measurements of cellular sizes and differential white blood cell counts, and the workload is constantly increasing, routine manual PBS examination is no longer practised in most modern laboratories. ${ }^{(1,2)}$ Instead, PBS examination is triggered either by the laboratory handling the blood sample or the physician who is looking after the patient. Once an indication is met, the PBS is first examined by a laboratory technician. Depending on the abnormalities spotted, the PBS may or may not be sent to a haematologist for further comment at a second level.

At the first level, the laboratory-initiated slide review is often triggered by abnormal results on blood cell counts or alarm flags on morphologic changes raised by the analyser. The International Society for Laboratory Hematology (ISLH) has proposed a set of criteria for which manual PBS examination is warranted, ${ }^{(3)}$ when certain numerical indices see a significant deviation from the normal or when abnormal flags are raised. Individual laboratories may adopt these rules and modify them to suit the characteristics of local patients. ${ }^{(4)}$ The quality of the slide review depends on the experience of the reporting laboratory staff, and the impact of the microscopic examination on clinical management has not been studied. Moreover, it is not clear if blood smears that do not fall under the criteria for manual review may still provide helpful clues for clinical diagnosis.

Clinicians may take the case to the second level by activating a haematologist for a specialist review or by referring the patient to a haematologist for further evaluation. The PBS is thus manually examined by the haematologist based on a combined clinical and laboratory indication. ${ }^{(2,5)}$ The results are usually regarded as the gold standard, but the usefulness of a haematologist-reviewed
PBS compared to a technician-reported PBS has not been systematically studied.

\section{METHODS}

This descriptive study was a retrospective clinical chart review, using data from a private paediatric haematology-oncology clinic in Singapore that received referrals and consultations from other medical practitioners in both outpatient and inpatient settings. The study period was from January 2016 to April 2017 (inclusive). Children aged 18 years or below whose primary physician requested a haematology and PBS examination by a haematologist were registered prospectively as the subjects of this study. We classified these children into one of five clinical scenarios based on prior experience: (a) isolated thrombocytopenia with or without bleeding symptoms; (b) unexplained bruises with normal platelet counts; (c) acute febrile illnesses with leucocytosis or leucopenia; (d) anaemia; and (e) others.

Demographic data was captured along with the initial automated CBC. This was compared with the ISLH criteria to check whether a laboratory-initiated PBS review was indicated. Comments from the laboratory slide review, if any, and the haematologist's comments were noted. These were compared with the patients' final diagnosis to make a decision on their usefulness. The haematologist's comment was considered 'diagnostic' when a specific clinical conclusion was made or there was an absence of disease, and 'informative' when no specific conclusion could be arrived at based on the slide review. The author has proposed a targeted approach to children with isolated thrombocytopenia in an unpublished paper. ${ }^{(6)}$ In particular, neoplastic cells, anomalous neutrophils, dysplastic changes and parasites have to be looked for and a diagnosis of immune thrombocytopenia or idiopathic thrombocytopenic purpura cannot be made unless these negative findings have been noted in the final report. 

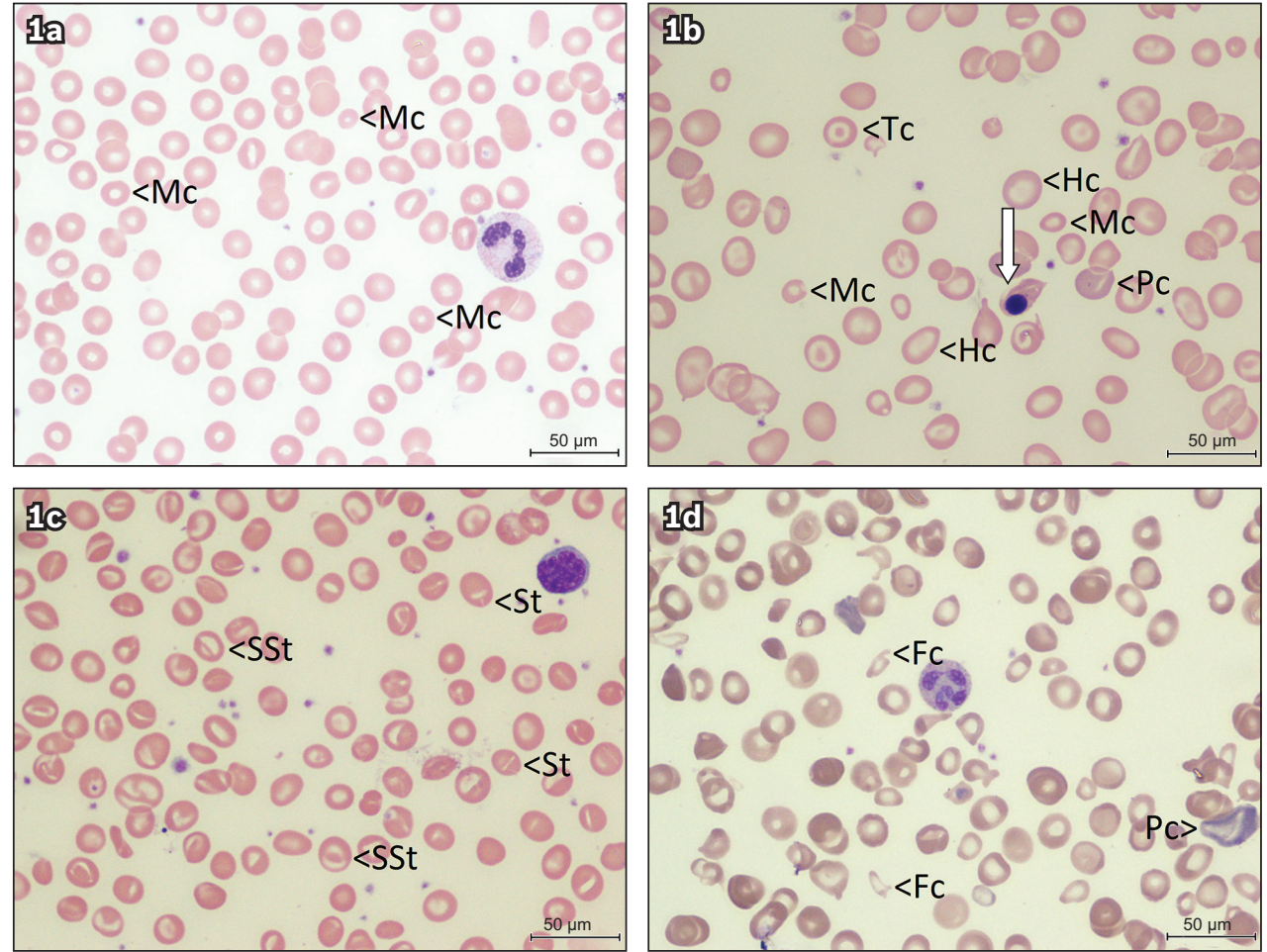

Fig. 1 Peripheral blood smear images from children with anaemia (Wright's, × 100) show (a) microcytic red cells (Mc) from Case 31 with iron deficiency (transferrin saturation 2.2\%, normal > 16\%); (b) severe anisopoikilocytosis, microcytic, hypochromic (Hc), polychromatic (Pc), and target cells (Tc) from Case 28 with haemoglobin $\mathrm{H}$ disease, with nucleated red cell in the middle (arrow); (c) stomatocytic red cells from Case 29 with single slit (St) and double slits (SSt) characteristic of Southeast Asian ovalocytosis; and (d) severe anisopoikilocytosis from Case 30 with polychromasia (Pc) and fragmented red cells (Fc), and a hypersegmented neutrophil in the middle. The child in (c) was otherwise well and the condition was found incidentally when the child presented for adoption. The serum vitamin B12 of the child in (d) was undetectable.

\section{RESULTS}

A total of 39 children with a mean age of 4.3 (range $0-16.2$ ) years were included in this study. Most $(n=20)$ of the patients were male. The clinical scenarios included ten cases of isolated thrombocytopenia, five cases of unexplained bruises, 11 cases of acute febrile illnesses, eight cases of anaemia, and five other cases. The clinical and laboratory findings are summarised in Table I.

$9(23 \%)$ of the CBC results did not fulfil the ISLH criteria for PBS review. However, diagnostic features were found in the haematologist's slide review in seven cases, including four cases of acquired platelet dysfunction with eosinophilia (or better termed idiopathic purpura with grey platelets), ${ }^{(7)}$ two cases of iron deficiency (with mean corpuscular volume $>75 \mathrm{fL}$ ), and one case of infectious mononucleosis due to Epstein-Barr virus infection.

Of the 30 cases in which PBS review was indicated, the laboratory-initiated review provided helpful clues in $4(13 \%)$ cases but misleading comments in $4(13 \%)$ other cases. For the other 22 cases, there were either no comments or only reminders about critical results. Whereas none of the laboratoryinitiated PBS reviews were diagnostic, 27 (69\%) out of 39 of the haematologist's comments were considered diagnostic and had specific conclusions. Examples are shown in Fig. 1. These were most noticeable among children with isolated thrombocytopenia (eight out of ten), unexplained bruises (four out of five), acute febrile illnesses (eight out of 11) and anaemia (seven out of eight). Review of PBS in children with incidentally found leucocytosis or neutropenia among the 'others' group had a low yield of diagnostic features.

\section{DISCUSSION}

Manual examination of the PBS requires expertise and time. The various formed elements of the blood display a spectrum of normal morphology under the microscope. Pathological changes can come in different shapes and may affect a single cell lineage or occur across the various cell types. Exogenous organisms may occasionally be discernible on the blood film, and artefacts from inadvertent handling or prolonged storage may complicate the PBS findings. Hence, PBS is an expensive test when it is read properly by an experienced person. ${ }^{(2)}$

Publications in refereed journals, textbooks and haematology atlases tend to state that PBS examination can contribute to clinical diagnosis in various haematological aspects. In the real world, perhaps only well-funded institutions with laboratories run by haematologists can afford to live up to these standards. Haematology laboratories in most other facilities are often run by laboratory-trained personnel or non-haematology-trained pathologists. In institutions run by the latter, the quality of PBS examination can vary, and it is not clear how standards are maintained. Hence, when a PBS examination is indicated, a medical practitioner should contact a haematologist directly or refer the patient to a haematologist for further management.

This review has shown that paediatric haematologists, who are trained in both paediatrics and paediatric haematology-oncology, are in the best position to review PBS from sick children. In this highly selected group of children, haematologist-reviewed PBS that incorporates the children's clinical signs and symptoms led to specific diagnoses in over two-thirds of cases. Indeed, haemolytic 
Table I. Clinical and laboratory findings before and after physician review.

\begin{tabular}{|c|c|c|c|c|c|c|c|c|c|c|}
\hline No. & $\begin{array}{l}\text { Gender, } \\
\text { age }\end{array}$ & $\begin{array}{c}\mathrm{Hb} \\
(\mathrm{g} / \mathrm{dL})\end{array}$ & $\begin{array}{c}\text { WBC } \\
\left(\times 10^{9} / \mathrm{L}\right)\end{array}$ & $\begin{array}{c}\text { ANC } \\
\left(\times 10^{9} / \mathrm{L}\right)\end{array}$ & $\begin{array}{c}\text { Plt } \\
\left(\times 10^{9} / \mathrm{L}\right)\end{array}$ & $\begin{array}{l}\text { Need } \\
\text { PBS? }\end{array}$ & $\begin{array}{l}\text { Laboratory } \\
\text { review }\end{array}$ & $\begin{array}{l}\text { Physician } \\
\text { remark }\end{array}$ & $\begin{array}{l}\text { Haematologist } \\
\text { review }\end{array}$ & Final diagnosis \\
\hline \multicolumn{11}{|c|}{ Isolated thrombocytopenia } \\
\hline 1 & $\mathrm{M}, 10 \mathrm{yr}$ & 12.3 & 2.76 & 0.72 & 7 & Yes & NSC & Diagnostic & $\begin{array}{l}\text { Platelet clumps/ } \\
\text { pseudothrombocytopenia }\end{array}$ & $\begin{array}{l}\text { Normal } \\
\text { haematology }\end{array}$ \\
\hline 2 & $\mathrm{M}, 1 \mathrm{yr}$ & 12.4 & 7.84 & 2.77 & 29 & Yes & NSC & Diagnostic & $\begin{array}{l}\text { Platelet clumps/ } \\
\text { pseudothrombocytopenia }\end{array}$ & $\begin{array}{l}\text { Normal } \\
\text { haematology }\end{array}$ \\
\hline 4 & F, 6 day & 16.6 & 7.84 & 3.06 & 17 & Yes & NSC & Informative & $\begin{array}{l}\text { Normal PBS; likely } \\
\text { neonatal alloimmune } \\
\text { thrombocytopenia }\end{array}$ & $\begin{array}{l}\text { Neonatal } \\
\text { alloimmune } \\
\text { thrombocytopenia }\end{array}$ \\
\hline 5 & $\mathrm{~F}, 6 \mathrm{yr}$ & 12.5 & 15.85 & 9.99 & 111 & Yes & $\begin{array}{l}\text { Large } \\
\text { platelet }\end{array}$ & Diagnostic & $\begin{array}{l}\text { Normal PBS; consistent } \\
\text { with ITP }\end{array}$ & ITP \\
\hline 6 & $\mathrm{~F}, 10 \mathrm{yr}$ & 10.2 & 4.99 & 3.39 & 70 & Yes & NSC & Diagnostic & $\begin{array}{l}\text { Normal PBS; consistent } \\
\text { with ITP }\end{array}$ & ITP \\
\hline 7 & $\mathrm{~F}, 1 \mathrm{yr}$ & 12.5 & 5.75 & 1.21 & 32 & Yes & NSC & Diagnostic & $\begin{array}{l}\text { Normal PBS; consistent } \\
\text { with ITP }\end{array}$ & ITP \\
\hline 8 & $\mathrm{M}, 1 \mathrm{yr}$ & 10.5 & 10.56 & 2.15 & 47 & Yes & NSC & Diagnostic & $\begin{array}{l}\text { Normal PBS; consistent } \\
\text { with ITP }\end{array}$ & ITP \\
\hline 9 & $\mathrm{M}, 6 \mathrm{mth}$ & 10.2 & 8.25 & 1.16 & 2 & Yes & NSC & Diagnostic & $\begin{array}{l}\text { Normal PBS; consistent } \\
\text { with ITP }\end{array}$ & ITP \\
\hline 10 & $\mathrm{M}, 1 \mathrm{mth}$ & 9.2 & 8.86 & 2.39 & 4 & Yes & NSC & Diagnostic & $\begin{array}{l}\text { Normal PBS; consistent } \\
\text { with ITP }\end{array}$ & ITP \\
\hline \multicolumn{11}{|c|}{ Unexplained bruises } \\
\hline 11 & $\mathrm{M}, 11 \mathrm{yr}$ & 10.1 & 2.97 & 1.16 & 324 & Yes & NSC & Informative & $\begin{array}{l}\text { Normal PBS; likely } \\
\text { aspirin effect from } \\
\text { treatment }\end{array}$ & $\begin{array}{l}\text { Salicylate } \\
\text { thrombocytopathy }\end{array}$ \\
\hline 13 & $\mathrm{M}, 5 \mathrm{yr}$ & 11.2 & 10.46 & 4.08 & 210 & No & ND & Diagnostic & $\begin{array}{l}\text { Grey platelets; likely } \\
\text { APDE }\end{array}$ & APDE \\
\hline 14 & $\mathrm{M}, 4 \mathrm{yr}$ & 11.4 & 9.36 & 2.61 & 146 & No & ND & Diagnostic & $\begin{array}{l}\text { Grey platelets; likely } \\
\text { APDE }\end{array}$ & APDE \\
\hline 15 & $\mathrm{~F}, 16 \mathrm{yr}$ & 12.7 & 7.36 & 3.88 & 156 & No & ND & Diagnostic & $\begin{array}{l}\text { Grey platelets; likely } \\
\text { APDE }\end{array}$ & APDE \\
\hline \multicolumn{11}{|c|}{ Acute febrile illness } \\
\hline 16 & $\mathrm{M}, 1 \mathrm{yr}$ & 11.1 & 3.09 & 0.12 & 130 & Yes & ND & Diagnostic & Mononucleosis & HHV6 infection \\
\hline 17 & $\mathrm{M}, 1 \mathrm{mth}$ & 11.1 & 9.75 & 6.83 & 11 & Yes & NSC & Diagnostic & $\begin{array}{l}\text { Mononucleosis; likely } \\
\text { congenital infection }\end{array}$ & $\begin{array}{l}\text { Congenital } \\
\text { infection } \\
\text { syndrome }\end{array}$ \\
\hline 18 & $\mathrm{M}, 11 \mathrm{yr}$ & 13.0 & 2.80 & 1.23 & 160 & Yes & ND & Diagnostic & Mononucleosis & $\begin{array}{l}\text { Non-bacterial } \\
\text { infection }\end{array}$ \\
\hline 19 & $\mathrm{M}, 3 \mathrm{yr}$ & 10.8 & 11.33 & 2.61 & 231 & No & ND & Diagnostic & Mononucleosis & EBV infection \\
\hline 20 & $\mathrm{~F}, 1 \mathrm{yr}$ & 12.6 & 4.19 & 1.30 & 197 & Yes & Blasts & Diagnostic & Mononucleosis & Roseola infantum \\
\hline 21 & M, 20 day & 9.4 & 13.57 & 13.70 & 83 & Yes & NSC & Diagnostic & $\begin{array}{l}\text { Microangiopathic } \\
\text { changes; likely DIC and } \\
\text { sepsis }\end{array}$ & $\begin{array}{l}\text { Klebsiella } \\
\text { septicaemia }\end{array}$ \\
\hline 22 & $F, 1$ yr & 9.1 & 12.06 & 3.98 & 572 & No & ND & Informative & $\begin{array}{l}\text { Inflammatory changes; } \\
\text { likely JIA }\end{array}$ & JIA \\
\hline 23 & $\mathrm{~F}, 13 \mathrm{yr}$ & 12.4 & 10.43 & 5.32 & 445 & Yes & Left shift & Informative & $\begin{array}{l}\text { Inflammatory changes; } \\
\text { likely acute infection }\end{array}$ & $\begin{array}{l}\text { Influenza B } \\
\text { infection }\end{array}$ \\
\hline 24 & $\mathrm{~F}, 14 \mathrm{yr}$ & 13.9 & 1.69 & 0.68 & 79 & Yes & NSC & Informative & $\begin{array}{l}\text { Inflammatory changes; } \\
\text { likely acute infection }\end{array}$ & $\begin{array}{l}\text { Non-bacterial } \\
\text { infection }\end{array}$ \\
\hline 25 & M, 4 yr & 13.4 & 27.40 & 4.11 & 221 & Yes & $\begin{array}{l}\text { Atypical } \\
\text { lymphocytes }\end{array}$ & Diagnostic & Lymphoblasts $10 \%$ & ALL \\
\hline
\end{tabular}




\begin{tabular}{|c|c|c|c|c|c|c|c|c|c|c|}
\hline No. & $\begin{array}{l}\text { Gender, } \\
\text { age }\end{array}$ & $\begin{array}{c}\mathrm{Hb} \\
(\mathrm{g} / \mathrm{dL})\end{array}$ & $\begin{array}{c}\text { WBC } \\
\left(\times 10^{9} / L\right)\end{array}$ & $\begin{array}{c}\text { ANC } \\
\left(\times 10^{9} / \mathrm{L}\right)\end{array}$ & $\begin{array}{c}\text { PIt } \\
\left(\times 10^{9} / \mathrm{L}\right)\end{array}$ & $\begin{array}{l}\text { Need } \\
\text { PBS? }\end{array}$ & $\begin{array}{l}\text { Laboratory } \\
\text { review }\end{array}$ & $\begin{array}{l}\text { Physician } \\
\text { remark }\end{array}$ & $\begin{array}{l}\text { Haematologist } \\
\text { review }\end{array}$ & Final diagnosis \\
\hline 26 & $\mathrm{~F}, 7 \mathrm{yr}$ & 11.8 & 3.74 & 0.41 & 68 & Yes & $\begin{array}{l}\text { No abnormal } \\
\text { cells }\end{array}$ & Diagnostic & Lymphoblasts $2 \%$ & ALL \\
\hline \multicolumn{11}{|c|}{ Anaemia } \\
\hline 27 & $\mathrm{~F}, 2 \mathrm{yr}$ & 5.9 & 14.46 & 7.34 & 1,077 & Yes & NSC & Diagnostic & $\begin{array}{l}\text { Haemolysis with } \\
\text { agglutinated RBCs }\end{array}$ & $\begin{array}{l}\text { Pneumonia with } \\
\text { cold agglutinins }\end{array}$ \\
\hline 28 & $\mathrm{~F}, 7 \mathrm{yr}$ & 5.3 & 4.36 & 1.79 & 234 & Yes & NSC & Diagnostic & $\begin{array}{l}\text { Haemolysis with } \\
\text { thalassaemic changes }\end{array}$ & $\begin{array}{l}\text { Haemoglobin } \mathrm{H} \\
\text { disease }\end{array}$ \\
\hline 29 & $\mathrm{M}, 1 \mathrm{mth}$ & 8.7 & 26.69 & 13.70 & 830 & Yes & NSC & Diagnostic & $\begin{array}{l}\text { Southeast Asian } \\
\text { ovalocytosis }\end{array}$ & $\begin{array}{l}\text { Southeast Asian } \\
\text { ovalocytosis }\end{array}$ \\
\hline 30 & $\mathrm{M}, 6 \mathrm{mth}$ & 4.3 & 4.42 & 0.40 & 103 & Yes & $\mathrm{McHc}$ RBCs & Diagnostic & $\begin{array}{l}\text { Haemolysis with } \\
\text { dysplastic nRBCs } \\
\text { \& hypersegmented } \\
\text { neutrophils consistent } \\
\text { with B12 deficiency }\end{array}$ & $\begin{array}{l}\text { Vitamin B12 } \\
\text { deficiency }\end{array}$ \\
\hline 31 & M, $5 \mathrm{yr}$ & 9.0 & 13.67 & 12.00 & 267 & No & ND & Diagnostic & $\begin{array}{l}\text { Microcytic, hypochromic } \\
\text { RBCs; likely iron } \\
\text { deficiency }\end{array}$ & Iron deficiency \\
\hline 32 & $\mathrm{~F}, 6 \mathrm{yr}$ & 13.5 & 7.04 & 3.40 & 261 & No & ND & Diagnostic & $\begin{array}{l}\text { Microcytic, hypochromic } \\
\text { RBCs; likely iron } \\
\text { deficiency }\end{array}$ & Iron deficiency \\
\hline 33 & F, 1 day & 5.6 & 18.58 & 13.00 & 348 & Yes & NSC & Informative & $\begin{array}{l}\text { No haemolysis; } \\
\text { many nRBCs; likely } \\
\text { fetomaternal transfusion }\end{array}$ & $\begin{array}{l}\text { Fetomaternal } \\
\text { transfusion }\end{array}$ \\
\hline 34 & $\mathrm{M}, 2 \mathrm{mth}$ & 10.6 & 8.27 & 2.47 & 335 & Yes & $\mathrm{McHc}$ RBCs & Diagnostic & Normal PBS & $\begin{array}{l}\text { Normal } \\
\text { haematology }\end{array}$ \\
\hline \multicolumn{11}{|c|}{ Others } \\
\hline 35 & $\mathrm{M}, 1 \mathrm{yr}$ & 12.5 & 7.08 & 0.92 & 347 & Yes & ND & Informative & Normal PBS; likely CBN & CBN \\
\hline 36 & $\mathrm{~F}, 1 \mathrm{yr}$ & 12.8 & 3.27 & 0.51 & 238 & Yes & ND & Informative & Normal PBS; likely CBN & CBN \\
\hline 37 & $\mathrm{~F}, 7 \mathrm{mth}$ & 12.8 & 10.26 & 0.32 & 517 & Yes & ND & Informative & Normal PBS; likely CBN & CBN \\
\hline 38 & $\mathrm{~F}, 11 \mathrm{yr}$ & 13.7 & 4.79 & 1.92 & 389 & No & ND & Informative & $\begin{array}{l}\text { Inflammatory changes; } \\
\text { likely Kikuchi's disease }\end{array}$ & Kikuchi's disease \\
\hline 39 & $\mathrm{~F}, 1 \mathrm{yr}$ & 14.5 & 28.8 & 12.00 & 380 & Yes & $\begin{array}{l}\text { Activated } \\
\text { neutrophils }\end{array}$ & Informative & $\begin{array}{l}\text { Inflammatory changes; } \\
\text { likely post-infection }\end{array}$ & $\begin{array}{l}\text { Post-infection } \\
\text { changes }\end{array}$ \\
\hline
\end{tabular}

ALL: acute lymphoblastic leukaemia; ANC: absolute neutrophil count; APDE: acquired platelet dysfunction with eosinophilia; CBN: chronic benign neutropenia; DIC: disseminated intravascular coagulation; EBV: Epstein-Barr virus; F: female; Hb: haemoglobin; HHV6: human herpesvirus 6; ITP: immune thrombocytopenia; JIA: juvenile idiopathic arthritis; M: male; McHc: microcytic and hypochromic; ND: not done; nRBCs: nucleated red blood cells; NSC: no specific comments/only reminder for critical result issued; PBS: peripheral blood smear; Plt: platelet; RBCs: red blood cells; WBC: white blood cell

anaemias, nutritional anaemias, immune thrombocytopenia and acquired thrombocytopathy can be diagnosed rapidly after careful examination of the PBS. The PBS also provides important clues for evaluation of childhood infectious diseases. It can also be diagnostic in malarial and other protozoal infections, although these were not investigated in this series of patients. ${ }^{(8)}$ The PBS can also reveal characteristic signs that may aid in the diagnosis of the Epstein-Barr virus, cytomegalovirus, and Bordetella pertussis infections. ${ }^{(9)}$ In children presenting with unexplained neurodevelopmental delay, the finding of lymphocyte vacuolation may suggest an underlying metabolic disease. ${ }^{(10)}$

Currently, most haematology laboratories have adopted rules, such as those published by the ISLH, and are examining the PBS from only $15 \%-20 \%$ of the CBC samples received. This allows the laboratories to handle hundreds of $\mathrm{CBC}$ tests on a daily basis without overly taxing their personnel. However, functional platelet disorders that are recognisable on blood film may be overlooked under the current selection criteria.
Moderately severe thalassaemia with apparently normal mean corpuscular volume and haemoglobin exceeding $8 \mathrm{~g} / \mathrm{dL}$ would also fail to be selected for PBS examination. ${ }^{(11)}$ In Southeast Asia and other regions where these disorders are not uncommon, communication and collaboration among medical practitioners, paediatric haematologists and the haematology laboratories can help to diagnose these conditions accurately from an otherwise simple blood test.

The findings from this study were limited by its small sample size and the highly selected nature of the subjects, which was determined by the referring physicians. Nevertheless, the haematologist-reviewed peripheral blood smear is an important adjunct in the evaluation of children with anaemia, bleeding disorders and acute febrile illnesses. Combined with clinical information, the slide review can provide diagnostic conclusions in the majority of cases. Further studies with a larger cohort from wider perspectives may shed more light on its clinical applications. 


\section{REFERENCES}

1. Gulati G, Song J, Florea AD, Gong J. Purpose and criteria for blood smear scan blood smear examination, and blood smear review. Ann Lab Med 2013; 33:1-7.

2. Bain BJ. Diagnosis from the blood smear. N Engl J Med 2005; 353:498-507.

3. International Consensus Group for Hematology Review. Suggested criteria for action following automated CBC and WBC differential analysis. In: Internationa Society for Laboratory Hematology [online]. Available at: http://www.islh.org/ web/consensus_rules.php. Accessed May 14, 2017.

4. Pratumvinit B, Wongkrajang P, Reesukumal K, Klinbua C, Niamjoy P. Validation and optimization of criteria for manual smear review following automated blood cell analysis in a large university hospital. Arch Pathol Lab Med 2013, 137:408-14.

5. Peterson P, Blomberg DJ, Rabinovitch A, et al. Physician review of the peripheral blood smear: when and why. An opinion. Lab Hematol 2001; 7:175-9.
6. Lee AC. Isolated thrombocytopenia in childhood: what if it is not immune thrombocytopenia (ITP)? Singapore Med J. In press.

7. Lee AC. Acquired platelet dysfunction with eosinophilia or idiopathic purpura with grey platelets? Ann Acad Med Singapore 2017; 46:167-8.

8. Lee AC. Hyper-reactive malarial splenomegaly and splenic infarct in a Caucasian toddler. Infect Dis Rep 2011; 3:e13.

9. Lee AC. Diagnosing infections from the peripheral blood smear. Hong Kong J Paediatr 2018; 23:25-8.

10. Anderson G, Smith VV, Malone M, Sebire NJ. Blood film examination for vacuolated lymphocytes in the diagnosis of metabolic disorders; retrospective experience of more than 2,500 cases from a single centre. J Clin Pathol 2005; 58:1305-10.

11. Lee AC. "Normal" mean corpuscular volume does not exclude the diagnosis of thalassaemia. Hong Kong J Paediatr 2015; 20:115-7. 